\title{
Urgences
}

\section{Le géant...}

\section{Marie-Andrée Massicotte}

Numéro 6, 4e trimestre 1982

URI : https://id.erudit.org/iderudit/025092ar

DOI : https://doi.org/10.7202/025092ar

Aller au sommaire du numéro

Éditeur(s)

Urgences

ISSN

0226-9554 (imprimé)

1927-3924 (numérique)

Découvrir la revue

Citer ce document

Massicotte, M.-A. (1982). Le géant... Urgences, (6), 53-60.

https://doi.org/10.7202/025092ar

Ce document est protégé par la loi sur le droit d'auteur. L'utilisation des services d'Érudit (y compris la reproduction) est assujettie à sa politique d'utilisation que vous pouvez consulter en ligne.

https://apropos.erudit.org/fr/usagers/politique-dutilisation/
Cet article est diffusé et préservé par Érudit.

Érudit est un consortium interuniversitaire sans but lucratif composé de l'Université de Montréal, l'Université Laval et l'Université du Québec à Montréal. Il a pour mission la promotion et la valorisation de la recherche. https://www.erudit.org/fr/ 
MARIE-ANDREE MASSICOTTE 
Le géant avait aspiré une bonne partie du liquide bleuâtre et salé.

Sur le plat quelques grumeaux gris et roux $s$ 'auréolaient encore de flaques miroitantes.

La marée était basse. 
L'éclat soyeux des mouvants reflets de la mer

Les lances vertes des jeunes herbes à travers le filet fané des foins courbés sous I'hiver

Le pépiement retrouvé de l'oiseau glanant les miettes en dentelles échappées à la nappe secouée

Le jour tout neuf à peine entamé

Entre les filières et les machines

la vie attend d'être gagnée 
Cette maison me ressemblait...

Les oiseaux jacassaient sur le toit de la galerie durant l'été des Indiens et l'hiver, dans les grandes poudreries, les épinettes courbaient la tête pour voir si le feu dans le poêle était bien pris. La chaux s'écaillait sur le gris des murs en multiples paysages et dans la chambre que le temps caressait en rêvant le soleil se reposait en toute quiétude.

Cette maison me ressemblait trop.

Au printemps, elle fuyait de toutes parts. 
Avec retenue et sobriété en tirant bien proprement la ligne modelée pour s'insérer élégamment entre les pages reliées au goût du jour

Avec panache les plumes rutilent pour éblouir font la roue mais la prudence sous-tend le filet du style les parures de gala cachent des garde-fous

Les communications sont parallèles ajustées à la courbe du temps Aucune dissension n'est permise Les messages sont chiffrés pour la survie des traducteurs

L'ensemble est raffiné avec juste ce qu'il faut de couleur Le verbe s'étant fait cher très cher trop cher les textes se portent courts cette année chez les grands intellectuels qui présentent leur nouvelle collection automne-hiver 
Le miroir tremblait...

La surface ondée de la nuit crachotait le tourment du souffle entravé par la frontière du présent

L'espace d'une bourrasque l'espoir crépitait la lueur clignotait avant de se perdre à nouveau dans I'eau trouble du miroir où le métrage des siècles déroulait ses longueurs d'aberrations et de prouesses à l'échelle de I'heure

Parfois les couturiers du verbe retouchaient quelques phrases en prévision du décadrage réinventaient l'image dans la courbe incertaine de la suite du temps

Et le miroir tremblait... Peut-être était-ce le vent 
Je m'oublie partout

Mais il se trouve toujours quelqu'un pour me remettre à ma place 


\section{LES ARTISTES,}

COMME LES DENTS DE SAGESSE, PERCENT

OU PAS. 